\title{
PEMETAAN EKOSISTEM INOVASI DI PERGURUAN TINGGI
}

\section{A MAPPING OF HIGHER EDUCATIONAL INNOVATION ECOSYSTEM}

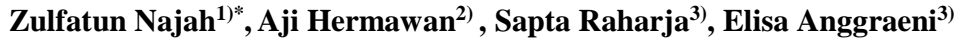 \\ ${ }^{1)}$ Jurusan Teknologi Pangan, Fakultas Pertanian, Universitas Sultan Ageng Tirtayasa \\ Jl. Raya Jakarta KM 4, Pakupatan, Serang, Banten, Indonesia \\ Email: zulfatun.najah@gmail.com \\ ${ }^{2)}$ Sekolah Bisnis Institut Pertanian Bogor. Gedung SB-IPB, Kampus IPB Gunung Gede \\ ${ }^{3)}$ Departemen Teknologi Industri Pertanian, FATETA IPB
}

Makalah: Diterima 10 Agustus 2017; Diperbaiki 18 April 2018; Disetujui 5 Mei 2018

\begin{abstract}
Innovation ecosystem mapping is a method to identify positions and roles of stakeholders. This research was an initial stage of research of building innovation ecosystem in higher education institution. Mapping of stakeholder's roles was conducted by classifying stakeholder's role based on framework of process innovation that include idea generation, research and development and commercialisation. This research used case study research design. Bogor Agricultural University (IPB) was choosen as object study because it contributed as the most active innovation producer during 2009-2016 period according to LIPI Indonesia Business Innovation Center. Data collection is done through interview and collecting related document such as Standard Operation Procedure (SOP). After conducting studies, there were 13 activities related to innovation process conducted by stakeholders which determine the development performance of IPB innovation ecosystem. Based on overlapping analysis, there were similarities of roles in innovation management of IPB that werefacilitating research cooperation, incubating, patenting and disseminating innovation. Based on gap analysis, all of commercialisation process stage was not done yet by the stakeholder that include developing and examinating product concept, bussiness analysis, developing product.
\end{abstract}

Keyword: ecosystem, higher education, innovation, mapping role

\section{ABSTRAK}

Pemetaan ekosistem inovasi merupakan sebuah metode yang dapat digunakan untuk mengidentifikasi posisi dan peran pemangku kepentingan. Peran pemangku kepentingan dipetakan dengan mengklasifikasikan peran tersebut sesuai dengan proses inovasi yaitu pembangkitan ide, riset dan pengembangan dan komersialisasi. Pemetaan ekosistem ini merupakan sebuah studi kasus di Institut Pertanian Bogor yang berkontribusi sebagai produsen inovasi paling aktif selama periode 2009-2016 sesuai Bussiness Innovation Center LIPI Indonesia. Pengumpulan data dilakukan melalui wawancara dan pengumpulan dokumentasi berupa Prosedur Operasional Baku (POB) kegiatan terkait. Setelah melakukan kajian, diperoleh 13 aktivitas yang terkait dengan proses inovasi yang dilakukan oleh pemangku kepentingan yang menentukan kinerja pengembangan lingkungan inovasi IPB. Berdasarkan analisis kesamaan peran, terdapat kesamaan peran di dalam manajemen inovasi IPB yaitu pada fasilitasi kerjasama penelitian, peran inkubasi, peran fasilitasi perlindungan hak kekayaan intelektual dan peran diseminasi inovasi dalam bentuk pameran. Berdasarkan analisis kesenjangan, peran proses tahapan komersialisasi seperti uji dan pengembangan konsep, analisis bisnis, pengembangan produk belum dilakukan oleh pemangku kepentingan IPB.

Kata kunci: ekosistem, pemetaan peran, inovasi, perguruan tinggi

\section{PENDAHULUAN}

Inovasi menjadi faktor utama yang memiliki dampak positif terhadap perkembangan daya saing dan ekonomi suatu negara. Beberapa peneliti telah membuktikan bahwa inovasi adalah suatu alat bagi perusahaan untuk bertahan di lingkungan dinamis dimana produk berubah secara cepat baik dari segi desain maupun aspek fungsionalnya (Jiao et al., 2011; Ortega dan Bagnato 2015). Inovasi adalah suatu proses untuk menghasilkan suatu ide baru dan mengubah ide menjadi sesuatu yang bernilai untuk memenuhi kebutuhan pengguna. Inovasi menterjemahkan peluang pasar menjadi sesuatu mendatangkan keuntungan bagi perusahaan (Okpara, 2007). Perguruan tinggi adalah salah satu agen inovasi nasional yang menjadi aktor utama yang menentukan keberhasilan ekosistem inovasi nasional. Dalam ruang lingkup inovasi nasional, perguruan tinggi berperan sebagai entitas generator pengetahuan, penghasil sumber daya manusia, dan sebagai produsen dan diseminator inovasi (Guerrero dan Urbano, 2012). Oleh sebab itu, lingkungan perguruan tinggi perlu didukung oleh lingkungan yang mendukung tumbuhnya inovasi. 
Lingkungan yang kondusif dapat dilihat sebagai sebuah ekosistem yang terdiri dari spesies spesies yang berinteraksi dalam lingkungannya. Ekosistem yang sehat akan menghasilkan lingkungan yang seimbang dan spesies yang sehat. Jika analogi ini dibawa ke ranah organisasi, maka organisasi yang inovatif adalah spesies yang sehat dan menjalankan perannya dengan baik di lingkungannya (Iansiti dan Levian, 2004). Ekosistem inovasi didefinisikan sebagai pengelolaan kolaboratif dari berbagai organisasi melalui kombinasi kemampuan individu secara koheren di dalam lingkungannya dalam menjawab permasalahan pasar (Adner, 2006). Ekosistem inovasi juga dapat diartikan interaksi entitas di dalam lingkungannya meliputi aktor, peran, infrastruktur, organisasi, aktivitas untuk membangun lingkungan inovasi yang dinamis (Regele dan Neck, 2012; Engler dan Kuslak, 2012). Dengan adanya lingkungan yang kondusif dimana aktor berinteraksi sesuai dengan posisi dan perannya, maka pengembangan teknologi dan inovasi dapat berjalan dengan baik. Oleh karenanya diperlukan pemetaan ekosistem inovasi untuk mengetahui aktor, peran, dan interaksinya dalam meningkatkan kinerja inovasi di perguruan tinggi

Pemetaan ekosistem digunakan sebagai alat analisis untuk memvisualisasi posisi dan struktur pemangku kepentingan di dalam sistem inovasi. Pemetaan ekosistem juga menjadi alat untuk mengetahui hubungan antar peran. Pemetaan ekosistem akan membantu untuk mengembangkan cetak biru ekosistem dan menyediakan wawasan mengenai ekosistem yang mungkin mendorong atau menghambat usaha inovasi. Pemetaan ekosistem penting dilakukan sebagai tahap awal dalam membangun ekosistem inovasi perguruan tinggi dan memberikan usulan perbaikan ekosistem inovasi perguruan tinggi. Aktor ekosistem inovasi perguruan tinggi berdasarkan perannya dibedakan menjadi pengambil keputusan, fasilitator, inovator, penyandang dana dan aktor pendukung. Secara lebih detail, aktor ekosistem inovasi perguruan tinggi terdiri dari mahasiswa, fakultas, peneliti, manajemen perguruan tinggi, dan unit bisnis perguruan tinggi.

Penelitian ini mengambil studi kasus Institut Pertanian Bogor. Tujuan umum dari paper ini adalah memaparkan ekosistem inovasi di Institut Pertanian Bogor (IPB). Diharapkan dengan memaparkan ekosistem inovasi IPB, maka peran pemangku kepentingan yang terkait dengan proses inovasi menurut Rohrbeck et al. (2009) dapat diidentifikasi. Peran pemangku kepentingan yang menjadi kajian tersebut yaitu peran yang terkait dengan proses pembangkitan ide, proses riset dan pengembangan dan proses komersialisasi.

\section{METODE PENELITIAN}

Penelitian ini menggunakan strategi penelitian studi kasus untuk memetakan struktur dan peran pemangku kepentingan, memaparkan mengapa dan bagaimana peran dilakukan beserta hasilnya. Studi kasus adalah strategi penelitian yang cukup kuat untuk memaparkan sebuah fenomena sosial dengan masih mempertahankan karakteristik dan konteks kondisi nyata secara menyeluruh (Yin 2003; Eisenhardt dan Graebner, 2007). Penelitian ini mengambil studi kasus Institut Pertanian Bogor (IPB) karena IPB adalah perguruan tinggi yang lebih banyak menghasilkan karya inovatif dibanding instansi lain di Indonesia menurut Bussiness Innovation Center periode 2009 - 2016. Responden penelitian ditentukan secara sengaja (purposive sampling) berdasarkan hasil observasi fungsi dan tugas pokok organisasi di IPB dengan mempertimbangkan keterkaitannya dengan ruang lingkup proses inovasi menurut Rohrbeck et al. (2009) dan OECD (2015). Ruang lingkup proses inovasi ditentukan berdasarkan tahapan proses inovasi menurut Rohrbeck et al. (2009) dan OECD (2015) (Gambar 1)

Tahapan riset dan pengembangan menurut Rohrbeck et al. (2009) adalah terpisah dan memiliki definisi yang berbeda. Riset adalah instrumen untuk memfasilitasi riset kolaborasi atau menghasilkan teknologi sedangkan pengembangan adalah kegiatan untuk menciptakan produk atau layanan baru (Rohrbeck et al., 2009). Pada penelitian ini, riset dan pengembangan merupakan suatu kesatuan aktivitas. Hal ini didukung oleh OECD (2015) yang menyatakan bahwa kegiatan riset terdiri dari riset dasar, riset terapan dan eksperimen pengembangan. Kegiatan pengembangan produk tidak dapat dipisahkan dari kegiatan riset dasar dan riset terapan karena produk yang dihasilkan oleh universitas bermula dari riset dasar dan riset terapan. Hal ini didukung dengan pernyataan bahwa aktivitas pengembangan terjadi setelah aktivitas penelitian dan merupakan aktivitas mengubah ilmu pengetahuan yang ditemukan menjadi produk yang berguna yang dapat dipasarkan (OECD, 2015).

Ruang lingkup penelitian adalah memetakan ekosistem inovasi perguruan tinggi dengan pendekatan peran (role based approach). Pendekatan ini telah digunakan untuk mengkarakterisasi entitas di dalam perguruan tinggi dan digunakan sebagai metode untuk pemetaan proses (Cho et al., 1998). Untuk mengidentifikasi peran pemangku kepentingan di dalam ekosistem inovasi perguruan tinggi IPB, wawancara mendalam dilakukan terhadap aktor yang terkait dengan aktivitas inovasi perguruan tinggi. Selain itu, pengumpulan data berupa prosedur operasional baku (POB) juga dilakukan untuk melengkapi hasil wawancara. Aspek yang didalami dalam pemetaan ekosistem inovasi adalah peran pemangku kepentingan, aktivitas organisasi dimana pemangku kepentingan terlibat, mekanisme aktivitas yang terjadi, hubungan antar pemangku kepentingan, dan 
adakah pemangku kepentingan lain yang terlibat pada pelaksanaan aktivitas tersebut.

Pemetaan ekosistem dilakukan dengan beberapa tahapan yaitu mendefinisikan ekosistem dan mengidentifikasi pemangku kepentingan, aturan, peran, input dan output. Identifikasi dapat dilakukan dengan menganalisis proses inovasi yang dilakukan aktor dan interaksi antar aktor. Analisis proses inovasi terletak pada lapisan pertama pada pemetaan sistem inovasi pada sistem digital dimana tahapan analisis yang perlu diketahui adalah pemangku kepentingan yang terlibat, peran masing-masing pemangku kepentingan, dan alur proses yang terjadi (Nachira et al., 2007). BPMN adalah teknik pemodelan object oriented yang dapat menggambarkan struktur dan perilaku dari objek dimana aliran objek (event, aktivitas, gateway dan sequence flow) sebagai elemen utama (White, 2008). Pada penelitian ini, BPMN dapat digunakan untuk memodelkan proses kegiatan inovasi dengan melihat interaksi yang terjadi setiap aktor. Pembuatan model menggunakan bantuan software Sybase Power
Designer 16.0. Pemetaan ekosistem dengan BPMN dapat digunakan sebagai alat untuk menganalisis aliran koordinasi dan alat untuk mengetahui tumpang tindih peran.

Dalam menganalisis peran pemangku kepentingan di dalam ekosistem inovasi IPB, responden diminta untuk mendeskripsikan peran dan aktivitas yang dilakukan didalam organisasinya khususnya terkait dengan ruang lingkup proses inovasi. Responden yang terkait di dalam ekosistem inovasi disajikan pada Tabel 1.

\section{HASIL DAN PEMBAHASAN}

\section{Analisis Peran Pemangku Kepentingan di Dalam Ekosistem Inovasi IPB}

Hasil wawancara dan pengumpulan data POB menghasilkan deskripsi peran pemangku kepentingan di dalam ekosistem inovasi IPB. Peran pemangku kepentingan tersebut dapat ditunjukkan pada Tabel 2.

Tabel 1. Sumber data pemetaan ekosistem inovasi perguruan tinggi

\begin{tabular}{lc}
\hline \multicolumn{1}{c}{ Pemangku kepentingan } & Sumber data \\
\hline $\begin{array}{l}\text { Rektor } \\
\text { Direktorat Riset dan Inovasi (DRI) }\end{array}$ & POB agenda riset \\
& POB agenda riset, POB permohonan dan pemeliharaan HKI, \\
Direktorat Pengembangan Bisnis (DPB) & POB komersialisasi inovasi (pameran) \\
& Wawancara \\
Direktorat Kemahasiswaan (DITMAWA) & Wawancara \\
Direktorat Karir dan Hubungan Alumni (DPKHA) & Wawancara \\
$\begin{array}{ll}\text { Lembaga Penelitian dan Pengabdian } \\
\text { (LPPM) }\end{array}$ & Wasyarakat \\
$\begin{array}{l}\text { PT. Bogor Life Science and Technology (PT.BLST) } \\
\text { Inkubator bisnis (incubie) }\end{array}$ & Laporan kegiatan PMW \\
$\begin{array}{l}\text { Pusat Studi (Pusat penelitian) } \\
\text { Fakultas }\end{array}$ & Rencana Induk Penelitian \\
Inovator & POB penelitian dan pengabdian masyarakat \\
& Wawancara \\
\hline
\end{tabular}

Tabel 2. Peran pemangku kepentingan di dalam ekosistem inovasi IPB

\begin{tabular}{|c|c|c|}
\hline Aktor & Komunitas & Peran \\
\hline \multicolumn{3}{|l|}{ Internal } \\
\hline Rektor & Pengambil keputusan & Berperan dalam menentukan kebijakan universitas. \\
\hline DRI & Fasilitator & $\begin{array}{l}\text { Berperan dalam: } \\
\text { - mengembangkan Rencana Induk Penelitian (RIP) dan pangkalan data } \\
\text { riset dan inovasi } \\
\text { - memfasilitasi pelaksanaan diseminasi dan pendayagunaan inovasi } \\
\text { prospektif, paten, dan HKI } \\
\text { - mengkoordinasi publikasi ilmiah }\end{array}$ \\
\hline DPB & Fasilitator & $\begin{array}{l}\text { Berperan dalam memfasilitasi pengelolaan sumberdaya dan IPTEKS } \\
\text { universitas terkait pengembangan bisnis dan kemitraan. }\end{array}$ \\
\hline LPPM & Fasilitator & $\begin{array}{l}\text { Berperan dalam memfasilitasi kegiatan terkait penelitian dan } \\
\text { pengabdian kepada masyarakat (PPM) yang meliputi penjaminan mutu, } \\
\text { mengkoordinasi kegiatan, fasilitasi administrasi kegiatan PPM yang } \\
\text { dilakukan pusat studi dan departemen. Selain itu sebagai koordinator } \\
\text { kegiatan pusat studi. }\end{array}$ \\
\hline
\end{tabular}




\begin{tabular}{|c|c|c|}
\hline Aktor & Komunitas & Peran \\
\hline PT. BLST & Fasilitator & $\begin{array}{l}\text { Berperan dalam : } \\
\text { - membentuk ventura baru, } \\
\text { - melakukan inkubasi inovasi, } \\
\text { - mengkomersialisasi hasil inovasi. }\end{array}$ \\
\hline IncuBie & Fasilitator & $\begin{array}{l}\text { Berperan dalam melakukan peningkatan kinerja UKM melalui } \\
\text { pendampingan UKM dan bisnis baru yang telah berjalan } 1 \text { tahun. }\end{array}$ \\
\hline Pusat Studi & Fasilitator & $\begin{array}{l}\text { Berperan dalam: } \\
\text { - mengembangkan kajian terkait bidang keilmuwan pusat studi } \\
\text { - melakukan kegiatan penelitian dan pengabdian masyarakat } \\
\text { - melakukan difusi / diseminasi inovasi }\end{array}$ \\
\hline Fakultas & Fasilitator & $\begin{array}{l}\text { Berperan dalam melakukan kendali mutu kegiatan pendidikan dan } \\
\text { penelitian. }\end{array}$ \\
\hline Departemen & Fasilitator & $\begin{array}{l}\text { Berperan dalam melakukan kegiatan kendali mutu kegiatan penelitian } \\
\text { dan pendidikan. }\end{array}$ \\
\hline DPKHA & Fasilitator & $\begin{array}{l}\text { Berperan dalam memfasilitasi kegiatan pengembangan kewirausahaan } \\
\text { mahasiswa melalui kegiatan Program Wirausaha Mandiri (PMW) }\end{array}$ \\
\hline DITMAWA & Fasilitator & $\begin{array}{l}\text { Berperan dalam memfasilitasi kegiatan pengembangan kreativitas } \\
\text { mahasiswa melalui kegiatan Program Kreativitas Mahasiswa (PKM). }\end{array}$ \\
\hline Peneliti & Inovator & Berperan dalam melakukan kegiatan penelitian dan pengembangan. \\
\hline $\begin{array}{l}\text { Mahasiswa } \\
\text { Eksternal }\end{array}$ & Inovator & Berperan dalam melakukan kegiatan penelitian \\
\hline Pemerintah & Penyandang Dana & Berperan dalam menyediakan dana kegiatan inovasi. \\
\hline UKM & Pendukung & $\begin{array}{l}\text { Berperan sebagai aktor pendukung kegiatan pengembangan } \\
\text { kewirausahaan mahasiswa dan pendampingan usaha. } \\
\text { - menyediakan tenaga ahli pendampingan bisnis (mentor) } \\
\text { - menyediakan fasilitas magang }\end{array}$ \\
\hline Industri & $\begin{array}{l}\text { Penyandang Dana dan } \\
\text { Pendukung }\end{array}$ & $\begin{array}{l}\text { Berperan sebagai partner kerjasama penelitian yaitu: } \\
\text { - menyediakan dana dan fasilitas riset } \\
\text { - menginformasikan topik strategis riset }\end{array}$ \\
\hline
\end{tabular}

Berdasarkan analisis peran pemangku kepentingan tersebut, aktivitas inovasi setiap pemangku kepentingan dapat dikarakterisasi berdasarkan fungsi aktivitasnya sesuai dengan proses inovasi menurut Rohrbeck et al. (2009). Klasifikasi setiap aktivitas berdasarkan 3 tahapan proses tersebut disajikan pada Tabel 3. Fungsi aktivitas setiap proses inovasi diidentifikasi berdasarkan Rohrbeck et al. (2009) adalah:

- Pembangkitan ide (idea generation) adalah aktivitas yang berkontribusi pada pengembangan ide baru (IG).

- Riset dan pengembangan (research and development) adalah aktivitas yang bertujuan untuk menghasilkan produk atau teknologi baru melalui kerjasama dengan inovator atau pemangku kepentingan lain $(R \& D)$.

Komersialisasi adalah aktivitas yang berkolaborasi dengan pemangku kepentingan lain dalam membawa produk dan teknologi ke pasar $(\mathrm{K})$.

\section{Pemetaan Ekosistem Inovasi Perguruan Tinggi}

Peran aktor selanjutnya dipetakan sesuai dengan klasifikasi fungsi prosesnya dan urutan kegiatannya. Pemetaan ekosistem pada kajian ini yang didasarkan pada peran setiap aktor disajikan pada Gambar 2. Ekosistem inovasi perguruan tinggi adalah interkoneksi pemangku kepentingan dalam melakukan aktivitasnya melalui kolaborasi dan kerjasama untuk menghasilkan lingkungan yang mendukung aktivitas inovasi perguruan tinggi (Regele dan Neck, 2012). Berdasarkan penelitian, interaksi ini dikembangkan dengan membangun interaksi pada peran, aktor, insentif, kelembagaan, dan aktivitas.

Berdasarkan analisis peran pemangku kepentingan tersebut, aktivitas inovasi setiap pemangku kepentingan dapat dikarakterisasi berdasarkan fungsi aktivitasnya sesuai dengan proses inovasi menurut Rohrbeck et al. (2009). Klasifikasi setiap aktivitas berdasarkan 3 tahapan proses tersebut disajikan pada Tabel 3.

\section{Pembangkitan Ide}

Pembangkitan ide inovasi di perguruan tinggi didukung oleh peran pemangku kepentingan IPB dalam menentukan topik riset strategis, penentuan peta jalan penelitian dan penentuan kebijakan riset. Kebijakan riset dikembangkan 7 tahun sekali oleh pakar sesuai Surat Keputusan (SK) rektor dengan mempertimbangkan agenda riset dan peta jalan penelitian yang disusun oleh fakultas dan pusat studi perguruan tinggi. 


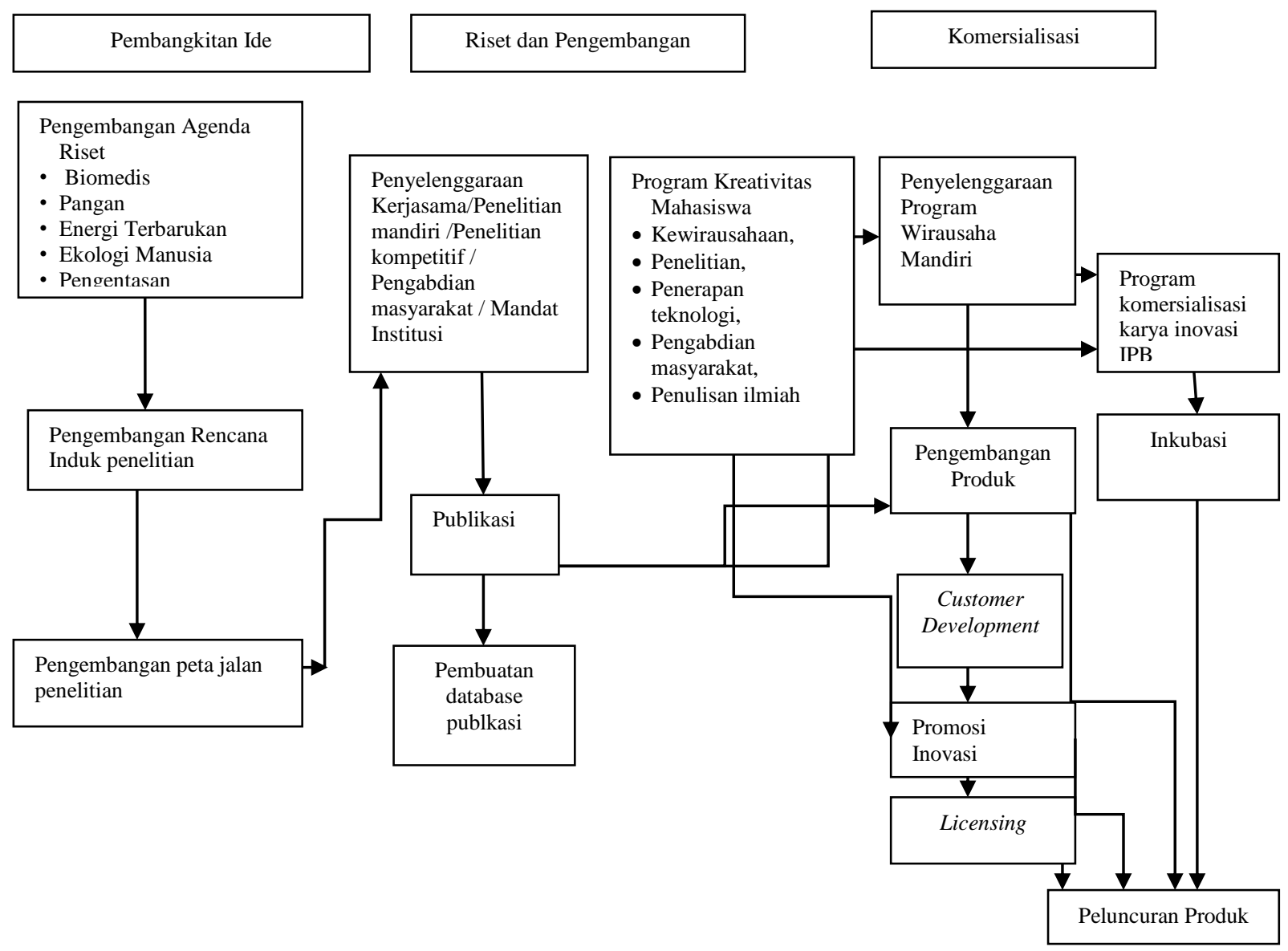

Gambar 2. Pemetaan peran ekosistem inovasi IPB

Tabel 3. Deskripsi aktivitas inovasi di lingkungan IPB

\begin{tabular}{|c|c|c|c|c|c|c|}
\hline \multirow[t]{2}{*}{ Aktivitas } & \multirow{2}{*}{$\begin{array}{c}\text { Pemangku } \\
\text { kepentingan } \\
\text { teridentifikasi }\end{array}$} & \multirow[t]{2}{*}{ Deskripsi aktivitas } & \multicolumn{3}{|c|}{$\begin{array}{c}\text { Tahapan } \\
\text { proses inovasi }\end{array}$} & \multirow[t]{2}{*}{ Pustaka } \\
\hline & & & IG & RD & $\mathbf{K}$ & \\
\hline $\begin{array}{l}\text { Inkubasi } \\
\text { inovasi }\end{array}$ & $\begin{array}{l}\text { Inkubator Bisnis } \\
\text { (IncuBie) }\end{array}$ & $\begin{array}{l}\text { Menginkubasi hasil inovasi yang } \\
\text { telah berjalan } 1 \text { tahun (UKM) dengan } \\
\text { melakukan pendampingan usaha dan } \\
\text { fasilitasi temu usaha }\end{array}$ & & & $\sqrt{ }$ & $\begin{array}{l}\text { Partner \& } \\
\text { Carisgold } \\
(2002)\end{array}$ \\
\hline $\begin{array}{l}\text { Inkubasi } \\
\text { inovasi }\end{array}$ & PT. BLST & $\begin{array}{l}\text { Menginkubasi dan } \\
\text { mengkomersialisasi hasil inovasi } \\
\text { peneliti IPB }\end{array}$ & & & $\sqrt{ }$ & $\begin{array}{l}\text { Partner \& } \\
\text { Carisgold } \\
\text { (2002) }\end{array}$ \\
\hline $\begin{array}{l}\text { Diseminasi } \\
\text { inovasi }\end{array}$ & DRI & $\begin{array}{l}\text { Membangun galeri inovasi sebagai } \\
\text { media diseminasi inovasi } \\
\text { Melakukan promosi inovasi }\end{array}$ & & & $\sqrt{ }$ & $\begin{array}{l}\text { Baglieri et } \\
\text { al. (2015) }\end{array}$ \\
\hline $\begin{array}{l}\text { Fasilitasi Paten } \\
\text { dan HKI }\end{array}$ & DRI & Memfasilitasi perlindungan HKI & & & $\sqrt{ }$ & $\begin{array}{l}\text { Partner \& } \\
\text { Carisgold } \\
(2002)\end{array}$ \\
\hline $\begin{array}{l}\text { Permohonan } \\
\text { paten }\end{array}$ & Pusat Studi & Memfasilitasi perlindungan HKI & & & $\sqrt{ }$ & $\begin{array}{l}\text { Partner \& } \\
\text { Carisgold } \\
(2002)\end{array}$ \\
\hline $\begin{array}{l}\text { Basis data } \\
\text { publikasi dan } \\
\text { inovasi }\end{array}$ & DRI & $\begin{array}{l}\text { Mengembangkan basis data } \\
\text { publikasi, dan inovasi }\end{array}$ & & $\sqrt{ }$ & & \\
\hline $\begin{array}{l}\text { Pengembangan } \\
\text { RIP }\end{array}$ & LPPM, DRI & Menyusun rencana induk penelitian & $\sqrt{ }$ & & & $\begin{array}{l}\text { Boeddrich } \\
\text { (2004) }\end{array}$ \\
\hline
\end{tabular}


Tabel 3. Deskripsi aktivitas inovasi di lingkungan IPB (Lanjutan)

\begin{tabular}{|c|c|c|c|c|c|c|}
\hline \multirow[t]{2}{*}{ Aktivitas } & \multirow{2}{*}{$\begin{array}{c}\text { Pemangku } \\
\text { kepentingan } \\
\text { teridentifikasi }\end{array}$} & \multirow[t]{2}{*}{ Deskripsi aktivitas } & \multicolumn{3}{|c|}{$\begin{array}{c}\text { Tahapan } \\
\text { proses inovasi }\end{array}$} & \multirow[t]{2}{*}{ Pustaka } \\
\hline & & & IG & $\mathrm{RD}$ & $\mathrm{K}$ & \\
\hline $\begin{array}{l}\text { Pengembangan } \\
\text { peta jalan } \\
\text { penelitian }\end{array}$ & Pusat studi & $\begin{array}{l}\text { Mengembangkan roadmap penelitian } \\
\text { berdasarkan agenda riset, riset yang } \\
\text { telah dilakukan, dan kebutuhan }\end{array}$ & $\sqrt{ }$ & & & $\begin{array}{l}\text { Boeddrich } \\
(2004)\end{array}$ \\
\hline $\begin{array}{l}\text { Pengembangan } \\
\text { basis data hasil } \\
\text { inovasi }\end{array}$ & LPPM & $\begin{array}{l}\text { Membuat data base inovasi yang } \\
\text { pendanaan inovasinya difasilitasi } \\
\text { oleh LPPM }\end{array}$ & & $\sqrt{ }$ & & \\
\hline Penelitian & Inventor & $\begin{array}{l}\text { Melakukan riset baik penelitian } \\
\text { mandiri, hibah maupun kolaborasi } \\
\text { antara inventor dengan industri }\end{array}$ & & $\sqrt{ }$ & & $\begin{array}{l}\text { Rohrbeck et } \\
\text { al. (2009) }\end{array}$ \\
\hline Penelitian & LPPM & $\begin{array}{l}\text { Memfasilitasi peneliti dan } \\
\text { penyandang dana dalam kerjasama } \\
\text { penelitian }\end{array}$ & & $\sqrt{ }$ & & $\begin{array}{l}\text { Rohrbeck et } \\
\text { al. (2009) }\end{array}$ \\
\hline $\begin{array}{l}\text { Pengabdian } \\
\text { masyarakat }\end{array}$ & LPPM & $\begin{array}{l}\text { Memfasilitasi peneliti dan } \\
\text { penyandang dana dalam kerjasama } \\
\text { penelitian pengabdian masyarakat }\end{array}$ & & $\sqrt{ }$ & $\sqrt{ }$ & $\begin{array}{l}\text { Rohrbeck et } \\
\text { al. (2009); }\end{array}$ \\
\hline $\begin{array}{l}\text { Program } \\
\text { kreativitas } \\
\text { mahasiswa } \\
(\text { PKM) }\end{array}$ & $\begin{array}{l}\text { Direktorat } \\
\text { Kemahasiswaan }\end{array}$ & $\begin{array}{l}\text { Memfasilitasi penyelenggaraan } \\
\text { kegiatan program kreatifitas } \\
\text { mahasiswa melalui proses : } \\
\text { 1. Seleksi } \\
\text { 2. Pemberian dana } \\
\text { 3. Evaluasi dan monitoring } \\
\text { 4. Penentuan pemenang }\end{array}$ & & $\sqrt{ }$ & & $\begin{array}{l}\text { Okpara } \\
(2007) ; \\
\text { Rohrbeck et } \\
\text { al. (2009) }\end{array}$ \\
\hline $\begin{array}{l}\text { Program } \\
\text { kewirausahaan } \\
\text { mahasiswa } \\
(\text { PMW) }\end{array}$ & DPKHA & $\begin{array}{l}\text { Memfasilitasi pengembangan usaha } \\
\text { baru (start up bisnis) mahasiswa }\end{array}$ & & & $\sqrt{ }$ & $\begin{array}{l}\text { Guerrero \& } \\
\text { Urbano } \\
(2012)\end{array}$ \\
\hline PMW & Perbankan & $\begin{array}{l}\text { Memberikan dana penyelenggaraan } \\
\text { kegiatan }\end{array}$ & & & $\sqrt{ }$ & \\
\hline $\begin{array}{l}\text { Komersialisasi } \\
\text { inovasi }\end{array}$ & PT BLST & $\begin{array}{l}\text { Membentuk ventura baru dari hasil } \\
\text { inovasi IPB } \\
\text { Melakukan komersialisasi hasil } \\
\text { inovasi }\end{array}$ & & & $\sqrt{ }$ & $\begin{array}{l}\text { Baglieri et } \\
\text { al. }(2015)\end{array}$ \\
\hline
\end{tabular}

Kebijakan riset ini tertuang dalam Rencana Induk Penelitian (RIP). Topik riset strategis perguruan tinggi ditetapkan melalui penyusunan agenda riset yang diselenggarakan oleh Direktorat Riset dan Inovasi Divisi Riset dan Publikasi dalam waktu 5 tahun sekali. Agenda riset disusun sesuai bidang ilmu perguruan tinggi yaitu pangan, ekologi manusia, pengentasan kemiskinan, energi, dan biomedis. Agenda riset disusun melalui suatu diskusi pakar yang merupakan pakar perwakilan fakultas berdasarkan kajian riset yang telah dilakukan fakultas dan isu permasalahan strategis yang terjadi di masyarakat. Hasil agenda riset disimpan dalam repository perguruan tinggi yang dapat diunduh oleh semua pemangku kepentingan perguruan tinggi. Peta aktivitas penyelenggaraan agenda riset disajikan pada Gambar 3.
Peta jalan penelitian disusun oleh masing-masing pusat studi perguruan tinggi terkait perkembangan riset keilmuwan masing-masing dan riset yang telah dilakukan dengan mempertimbangkan kebutuhan masyarakat. Peta jalan penelitian juga disusun oleh fakultas melalui diskusi dengan masing-masing departemen mengenai isu strategis yang berkembang dan kegiatan penelitian yang telah dilakukan departemen dan fakultas. Pemetaan aktivitas peta jalan penelitian disajikan pada Gambar 4. Peta proses pembangkitan ide dimulai dari proses penentuan agenda riset, penentuan peta jalan penelitian dan penentuan rencana induk penelitian. Peta aktivitas penentuan Rencana Induk penelitin perguruan tinggi disajikan pada Gambar 5. 
Sistem pengelolaan ide di IPB dilakukan oleh pusat studi, fakultas dan DRI pada tahapan pembangkitan ide dan penerimaan ide. Pembangkitan ide merupakan proses paling awal dalam tahapan proses inovasi. Pengelolaan ide inovasi merupakan proses strukturisasi berbagai jenis ide berdasarkan fungsi urutan dengan aktivitasnya yang berfokus pada penguatan ide baik dari dalam maupun dari luar lingkungan perguruan tinggi. Ide inovasi dapat berasal dari permintaan pasar (market push) maupun dari dorongan teknologi (technology pull). Pembangkitan ide ini ditentukan berdasarkan beberapa faktor seperti pertimbangan strategi, keterkaitan ide terhadap target pemakai dan sistematisasi struktur fase identifikasi ide (Boeddrich, 2004). Tahapan pengelolaan ide suatu institusi riset ditunjukkan pada Gambar 6 .

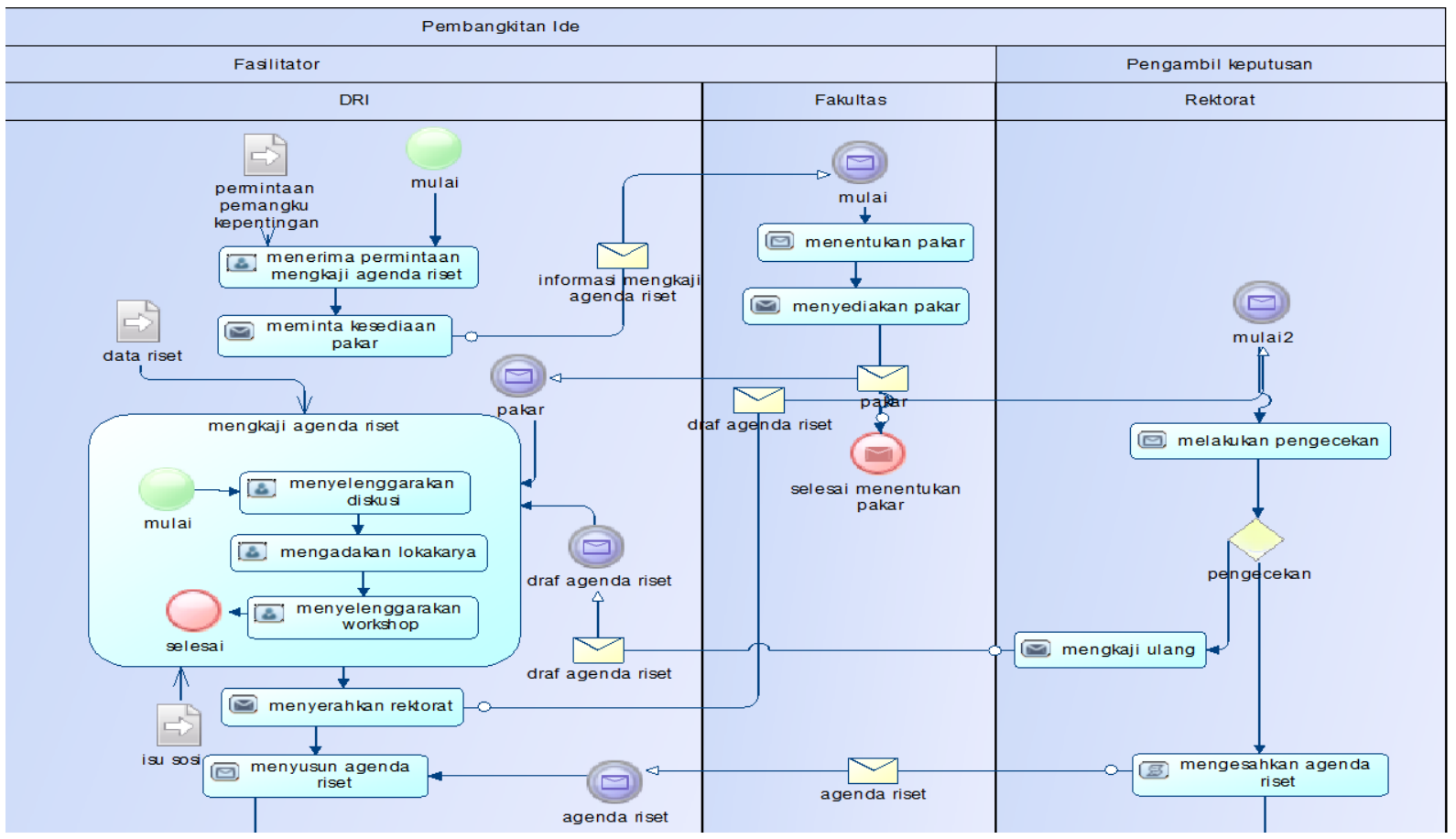

Gambar 3. Pemetaan aktivitas pada pengembangan agenda riset

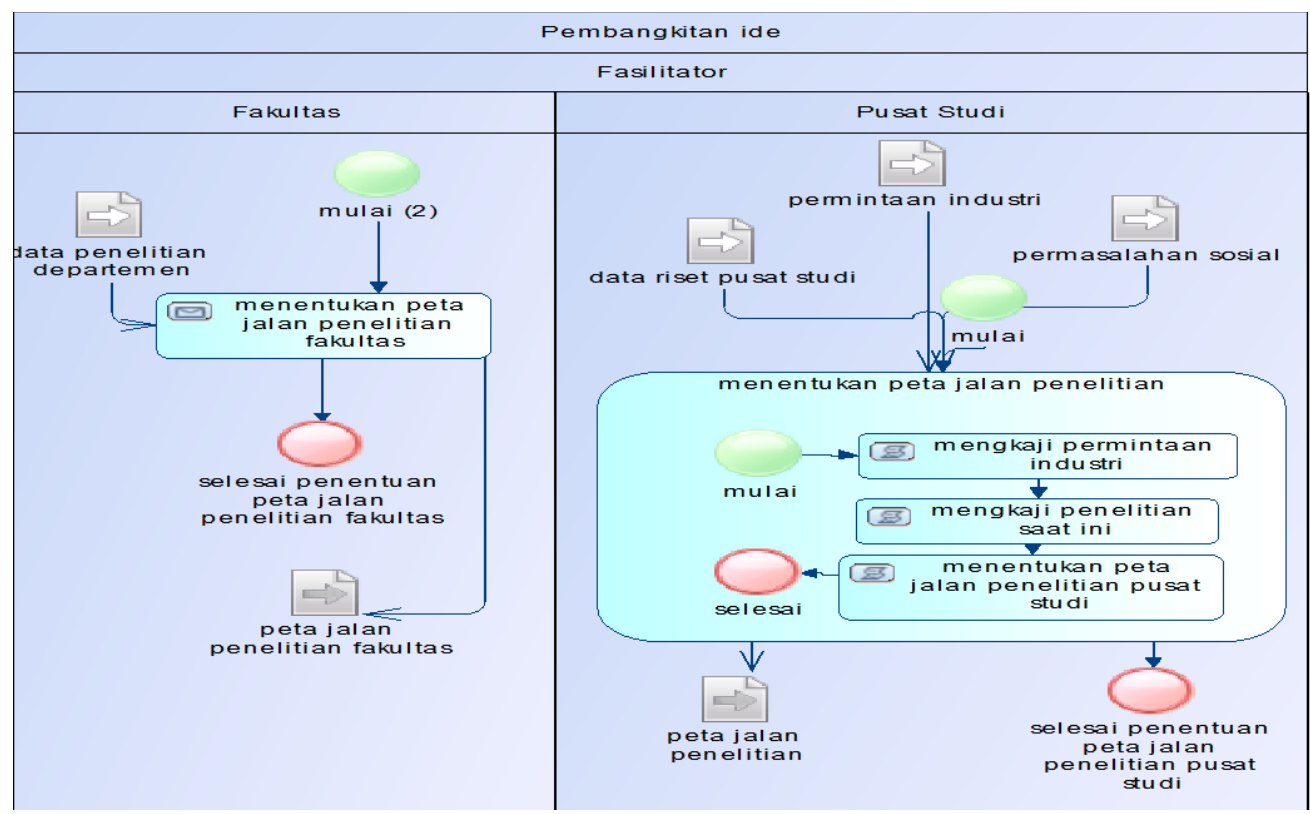

Gambar 4. Pemetaan aktivitas pada penentuan peta jalan penelitian. 


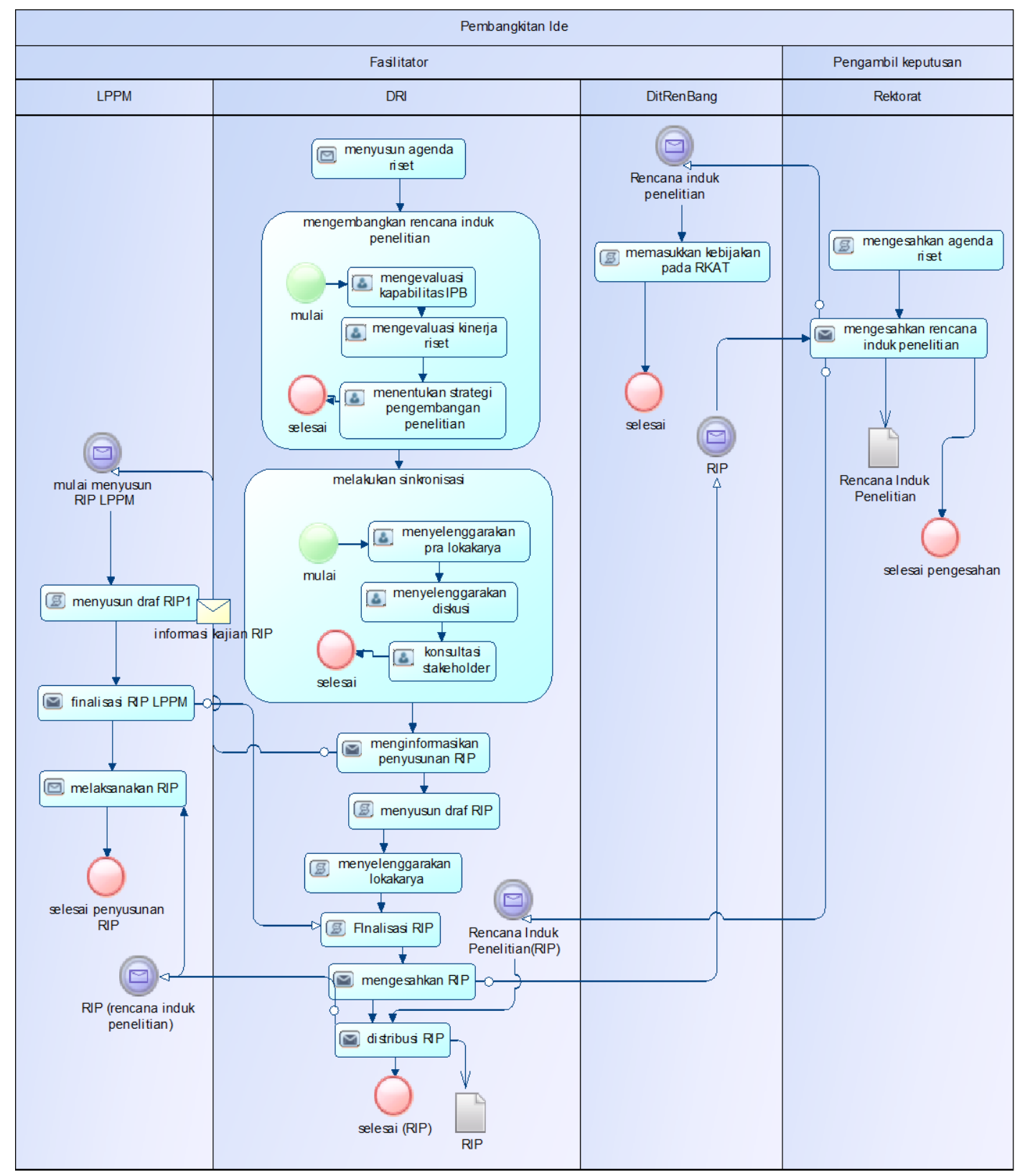

Gambar 5. Pemetaan aktivitas pada penentuan Rencana Induk Penelitian

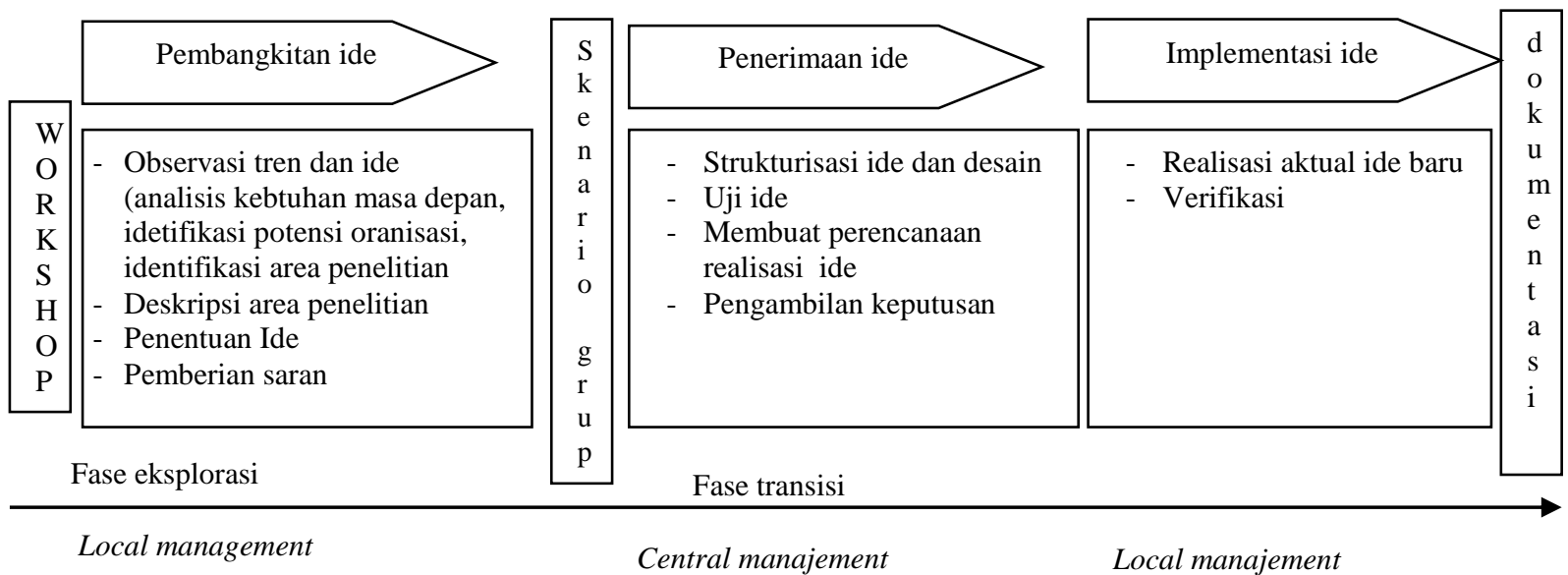

Gambar 6. Tahapan idea management system (Voight dan Brem, 2009; Boeddrich, 2004) 
Kelemahan proses pembangkitan ide yang dilakukan oleh manajemen IPB adalah terpakunya tren ide yang dihasilkan pada dorongan teknologi. Ameka dan Dhewanto (2013) mengungkapkan bahwa sebagian invensi yang dihasilkan oleh perguruan tinggi masih disebabkan dorongan teknologi dan keilmuwan. Hal ini didukung juga dari hasil FGD yang menyatakan: "Ide riset perlu mempertimbangkan kesesuaiannya dengan kebutuhan industri. Invensi yang telah dikembangkan inventor IPB ternyata telah dikembangkan oleh industri sementara industri sedang mengembangkan inovasi yang lain". "Dengan melihat perguruan tinggi lain di luar negeri, perguruan tinggi menggunakan tenaga ahli yang mengerti market intellegent dalam menentukan kebijakan agenda riset".

\section{Riset dan Pengembangan}

Kegiatan riset di perguruan tinggi khususnya IPB terbagi menjadi tiga fase riset berdasarkan fungsinya yaitu riset dasar, riset terapan dan riset aksi (IPB, 2012). Riset dasar adalah domain utama dari kegiatan penelitian perguruan tinggi dimana peneliti melakukan kegiatan eksperimen untuk mengembangkan suatu ilmu pengetahuan tertentu dan diarahkan pada penemuan teori baru, pengembangan teori yang ada, dan pengamatan fakta tanpa memperhatikan apakah pekerjaan yang dilakukan menghasikan sesuatu yang secara praktik berguna (Palys, 2008). Riset terapan merupakan pengembangan ilmu yang dihasilkan dari riset dasar dengan menghubungkan antara teori dengan kehidupan nyata untuk menyelesaikan suatu permasalahan dan menghasilkan teori terapan (OECD 1981). Jenis penelitian yang dilakukan IPB juga meliputi riset aksi yaitu penelitian yang lebih mengarah pada aksi-aksi sosial yang berhubungan dengan manusia dengan tujuan untuk memperbaiki sesuatu. Perguruan tinggi sebagai agen transfer pengetahuan saat ini lebih banyak melakukan kegiatan riset dasar. Hal ini didukung oleh keterangan DRI dan LPPM bahwa riset yang dilakukan oleh inovator sebagian besar masih merupakan riset dasar. Inovator mengungkapkan: "Pendanaan riset di lingkungan IPB sebagian besar berasal dari dana hibah riset kementerian riset dan teknologi pendidikan tinggi”. DRI mengungkapkan : "Skema pendanaan riset memiliki jangka waktu tertentu dan umumnya 3 tahun, sedangkan kegiatan penelitian hingga menghasilkan inovasi membutuhkan waktu lebih lama dari jangka waktu skema pendanaan riset tersebut. Pada saat pengajuan dana hibah selanjutnya, umumnya topik penelitian tidak meneruskan penelitian sebelumnya karena tren topik penelitian sudah berubah."

Jenis penelitian berdasarkan asal pendanaannya dibedakan menjadi penelitian hibah dan joint research. Riset di perguruan dapat dilakukan oleh peneliti melalui skema pendanaan hibah dari Pemerintah melalui kementerian riset dan teknologi pendidikan tinggi (Kemenristekdikti) maupun dari industri. Joint research dengan industri dapat dilakukan oleh inovator karena terdapat permintaan industri terkait permasalahan tertentu yang terjadi di industri. Penelitian yang pendanaannya berasal dari dana hibah dilakukan peneliti melalui skema seleksi dan evaluasi pengajuan ide riset kepada penyandang dana dengan fasilitasi dari LPPM. Jangka waktu riset ini adalah satu tahun. Kegiatan pengabdian masyarakat juga dilakukan oleh IPB dengan pelaksana adalah pusat studi atau fakultas/ departemen melalui LPPM. Salah satu bentuk kegiatan pengabdian masyarakat tersebut adalah bina desa.

Publikasi menjadi salah satu tolak ukur kinerja inovasi suatu perguruan tinggi. Hasil dari invensi yang dihasilkan inventor dapat berupa publikasi. Koordinator data basis publikasi yang dihasilkan perguruan tinggi difasilitasi oleh Direktorat Riset dan Inovasi (DRI) Divisi Riset dan Publikasi. Publikasi hasil inovasi perguruan tinggi IPB akan disimpan dalam repository IPB dan google play sehingga dapat diakses oleh semua pemangku kepentingan IPB. DRI juga melakukan fasilitasi pelaksanaan diseminasi dan pendayagunaan paten dan HKI yang secara khusus dilakukan oleh Divisi Paten dan Inovasi. Pendayagunaan paten dan HKI dilakukan melalui pameran, temu bisnis dan promosi inovasi pada Bussiness Innovation Center masingmasing dilakukan setiap tahun. Pameran dilakukan untuk produk-produk inovasi yang memiliki prototipe sedangkan temu bisnis dilakukan oleh DRI dengan fasilitasi dari Direktorat Pengembangan Karir dan Hubungan Alumni (DPKHA) selama 1 tahun sekali dengan mengundang alumni IPB untuk mengenalkan dan mempromosikan inovasi. Diseminasi inovasi juga dilakukan dengan pembentukan galeri inovasi IPB (IPB, 2013) .

Kegiatan inovasi mahasiswa sebagian besar dihasilkan melalui kegiatan kreativitas. Program kreativitas mahasiswa (PKM) merupakan ajang bagi mahasiswa untuk memvisualisasi ide kreatifnya dan berkarya seluas mungkin dengan pendanaan dari Kemenristekdikti. Program ini dilaksanakan selama satu tahun mulai Januari sampai Desember dengan difasilitasi oleh direktorat kemahasiswaan (DITMAWA) dengan skema pengajuan proposal, seleksi oleh Kemenristekdikti hingga pelaksanaan kegiatan, pelaporan dan evaluasi kegiatan. Program PKM ini terbagi menjadi 5 bidang yaitu kewirausahaan, penelitian, penerapan teknologi, pengabdian masyarakat, dan penulisan ilmiah. DITMAWA berperan sebagai fasilitator, sedangkan proses seleksi dan penilaian dilakukan oleh pakar dari Kemenristekdikti. Peta aktivitas penyelenggaraan PKM ini disajikan pada Gambar 7. 


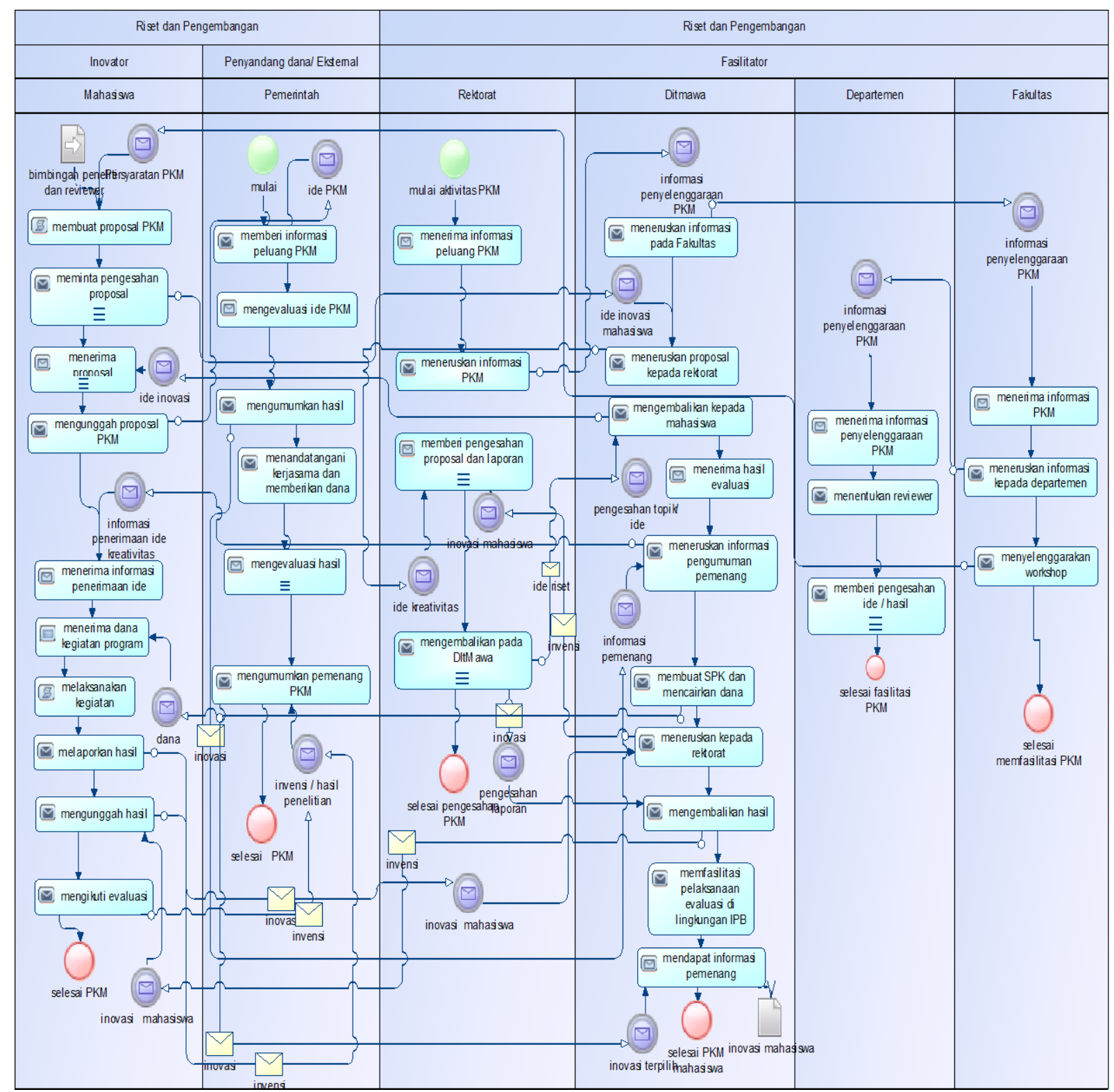

Gambar 7. Peta aktivitas penyelenggaraan PKM

\section{Komersialisasi}

Program lanjutan PKM adalah program wirausaha muda mandiri dimana perguruan tinggi melakukan pembinaan kewirausahaan kepada wirausaha muda dengan fasilitasi dari Direktorat Karir dan Hubungan Alumni (DPKHA) atau CDA (Carier Development Affair) dan penyandang dana dari Bank Mandiri. Program ini dapat dikatakan sebagai program lanjutan dari PKM. Program dilaksanakan selama satu tahun dengan peserta terpilih diutamakan yang telah memiliki bisnis. Masing-masing peserta diberikan mentor yang merupakan pakar dari akademis, pelaku bisnis dan UKM untuk meningkatkan kinerja bisnis peserta. Tujuan dari program adalah membentuk wirausaha muda melalui pembentukan bisnis baru. Peta aktivitas penyelenggaraan kegiatan wirausaha muda disajikan pada Gambar 8.
Komersialisasi dilakukan oleh unit bisnis perguruan tinggi yaitu PT. Bogor Life Science and Technology (PT. BLST). Tahapan proses ini dapat dilihat pada pemetaan proses pada BPMN. Tahapan proses ini dimulai dari proses seleksi inovasi yang prospektif dikembangkan menjadi ventura baru dengan menggunakan Technology Readiness Level (TRL) dengan penilai TRL adalah pakar yang ditunjuk sesuai SK Rektor (Gambar 9). Inovasi terpilih selanjutnya diinkubasi di PT. STP (PT. Science Technology Park, anak perusahaan dari PT. BLST) dan dilakukan pengembangan pasar. Bussiness Model Canvas (BMC) digunakan sebagai alat untuk customer development dalam menginkubasi inovasi. Hasil inkubasi inovasi oleh PT BLST adalah bisnis baru anak perusahaan PT BLST dan menjadi aset dari perguruan tinggi. Sistem pembagian royalti kemudian ditentukan antara inovator, IPB, dan PT. BLST. 


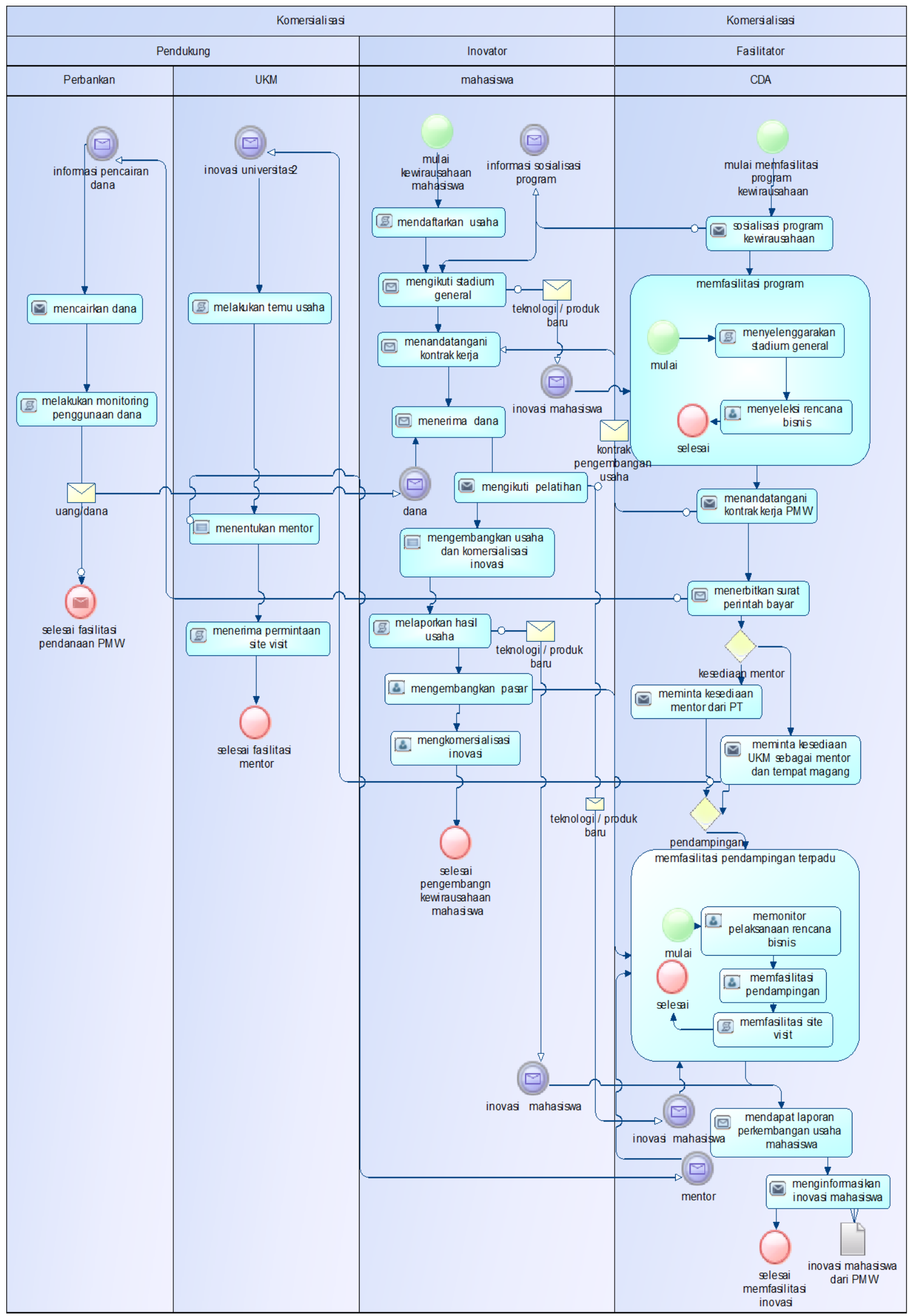

Gambar 8. Peta aktivitas penyelenggaraan Program Wirausaha Muda 


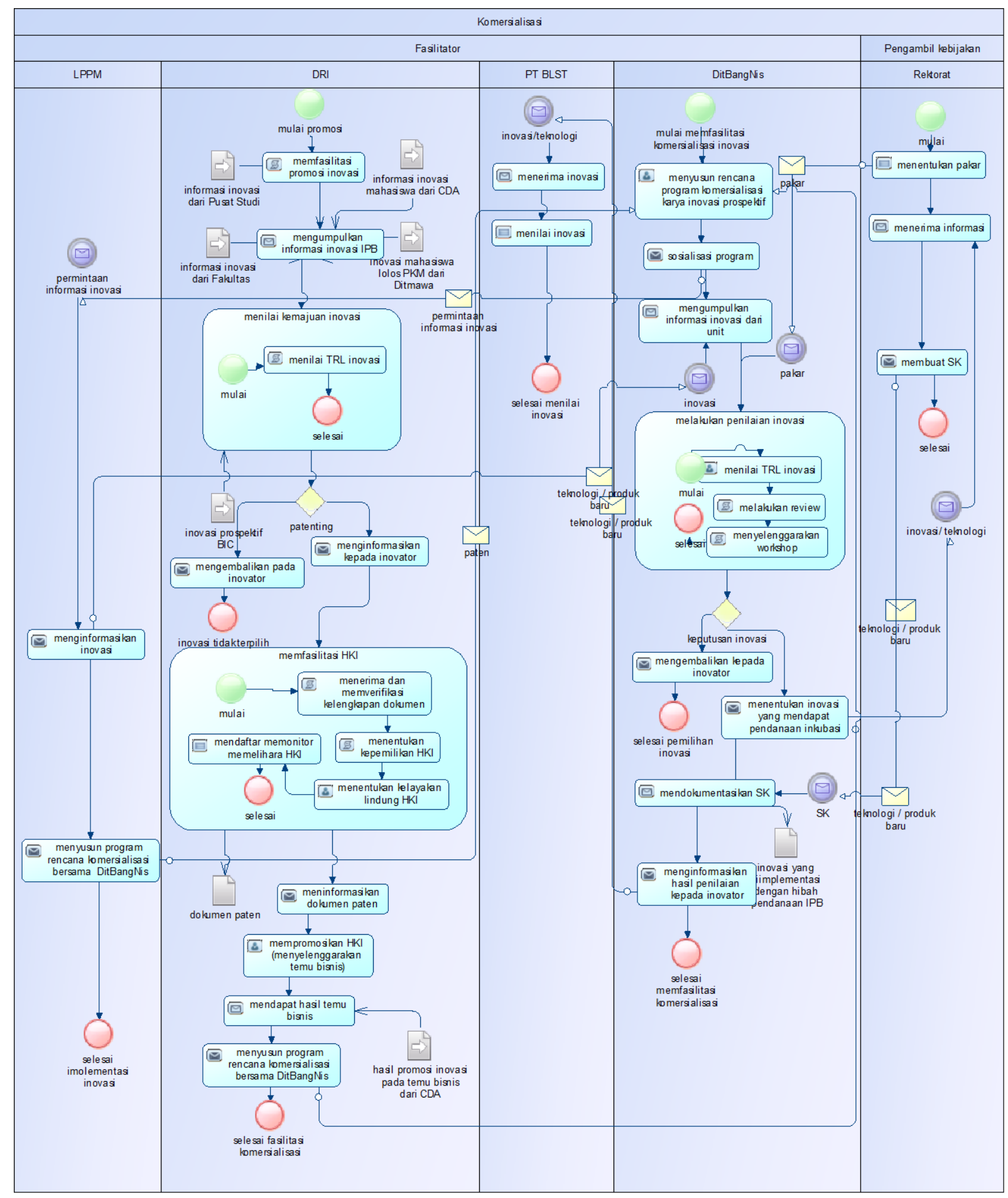

Gambar 9. Peta aktivitas seleksi inovasi

Selain membentuk bisnis baru, PT. BLST juga berperan dalam memasarkan produk inovasi melalui outlet khusus produk inovasi IPB. Bentuk komersialisasi hasil inovasi dapat berupa lisensi, dimana PT BLST juga memfasilitasi dalam memasarkan dan melakukan negosiasi lisensi dengan industri pemakai. Fasilitasi inkubasi juga dilakukan oleh Incubator bisnis (IncuBie) dimana instansi ini menginkubasi UKM atau inovator dengan lama bisnis berjalan 1 tahun baik inovator IPB maupun bukan civitas IPB. Incubie bertindak sebagai pendamping dan fasilitator temu usaha inovator dengan pelaku usaha lain (Gambar 10).

Berdasarkan matriks proses (Tabel 3), diketahui bahwa terdapat peran yang sama dalam manajemen inovasi IPB yaitu fasilitasi pengajuan paten, diseminasi dan promosi inovasi, inkubasi, dan fasilitasi kerjasama peneliti dengan penyandang dana. Fasilitasi perlindungan hak kekayaan intelektual difasilitasi oleh pusat studi IPB dan DRI. Diseminasi inovasi melalui pameran hasil inovasi IPB difasilitasi oleh pusat studi dan DRI. 


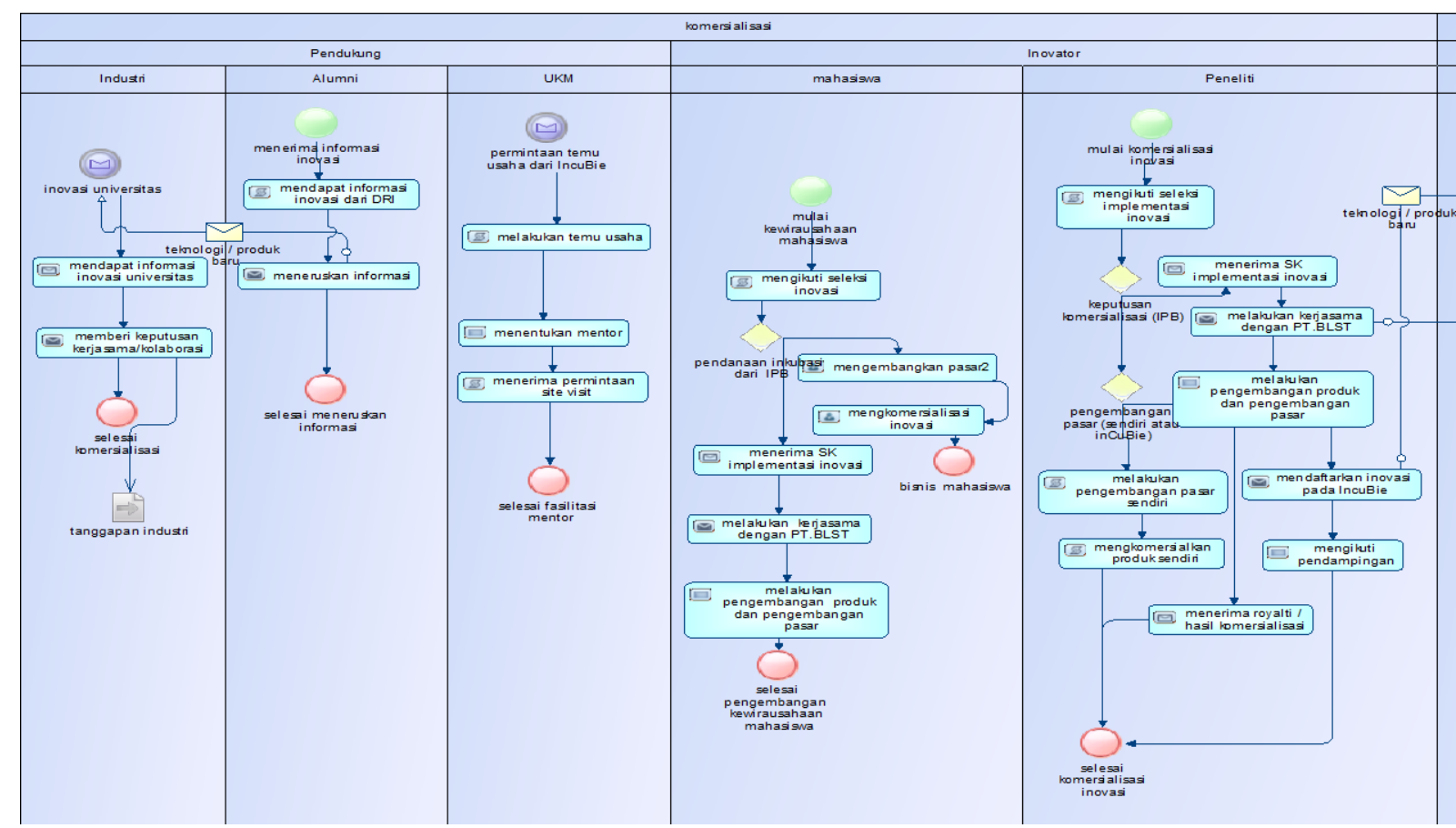

Gambar 10 (a). Peta aktivitas inkubasi inovasi dan komersialisasi inovasi yang dilakukan aktor pendukung dan inovator

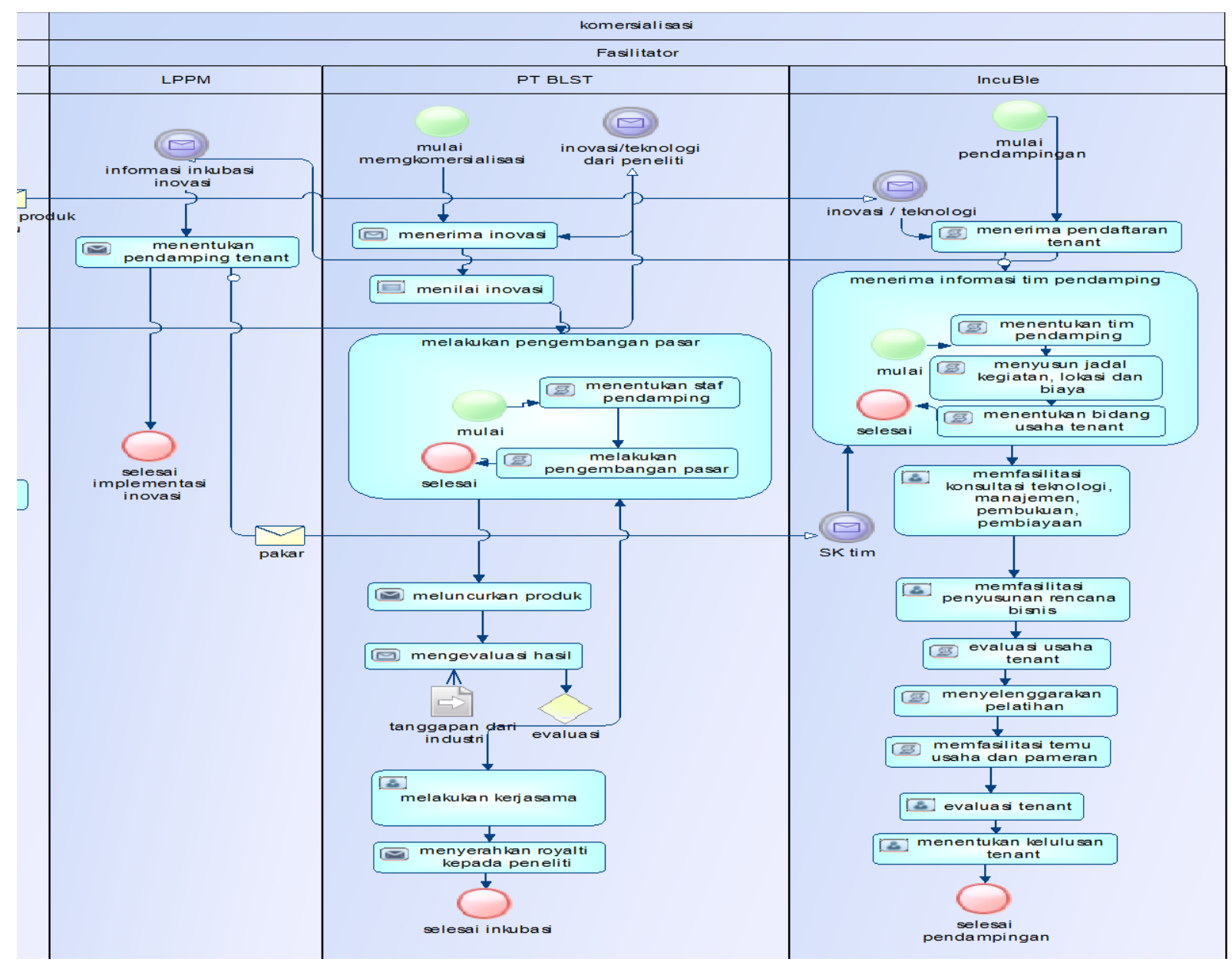

Gambar 10 (b). Peta aktivitas inkubasi inovasi dan komersialisasi inovasi yang dilakukan oleh fasilitator 
Sebagai aktor dalam ekosistem, DRI dan pusat studi melakukan aktivitas yang sama dengan sumber daya yang sama dan hasil yang sama. Pada proses komersialisasi khususnya pada proses inkubasi, proses inkubasi dilakukan oleh inkubator bisnis (Incubie) dan PT BLST. Dalam ekosistem inovasi, kedua aktor melakukan aktivitas yang sama namun dengan sumber daya, mekanisme proses dan instrumen yang berbeda. Hasil dari proses kedua aktor tersebut adalah sama yaitu menghasilkan ventura baru dengan mekanisme kepemilikan ventura baru yang berbeda. Incubie melakukan inkubasi dengan melakukan pendampingan dan sebagai fasilitator. PT. BLST melakukan inkubasi pada produk baru dan melakukan pendampingan, pengembangan pasar dan membentuk ventura baru dibawah PT. BLST

Kesamaan peran juga terjadi pada peran fasilitasi kerjasama penelitian IPB yang dilakukan oleh fakultas, LPPM, dan Rektorat. Setiap kerjasama yang dilakukan oleh inovator baik dari pusat studi maupun dosen dilakukan dengan pengesahan dari Fakultas, LPPM atau Rektor. Hal ini dikarenakan sistem inovasi IPB yang terdesentralisasi dan inovator dapat melakukan kerjasama melalui aktor tersebut.

Komersialisasi adalah kegiatan membawa produk ke pasar (Rhorbeck et al., 2009). Proses komersialisasi teknologi dicirikan melalui proses menjembatani ide produk dan kebutuhan pasar, proses pengembangan pasar, proses inkubasi, proses meluncurkan produk, promosi dan pengembangan berkelanjutan (Takata, 2011) (Tabel 4). Proses komersialisasi lain diungkapkan oleh Cooper (2006). Pada sistem komersialisasi, Cooper (2006) mengembangkan proses komersialisasi yang diadopsi oleh PT. BLST dalam menginkubasi hasil inovasi. PT. BLST mengambil peran pada uji pasar dan komersialisasi pada rangkaian proses state gate yang dikembangkan Cooper (2006). Kriteria pada setiap tahapan proses kemudian dikembangkan oleh
Bhuiyan (2011) dan Amue dan Adiele (2012) (Gambar 11).

Berdasarkan hal ini, diketahui bahwa terdapat kekosongan proses yaitu dari tahapan kualifikasi konsep hingga tahapan pengembangan produk karena yang dilakukan PT BLST adalah kualifikasi pasar dan peluncuran produk. Sementara itu, incubator bisnis melakukan inkubasi inovasi yang bisnisnya telah berjalan 1 tahun (bukan produk baru) untuk memperluas pasar. Proses yang dilakukan adalah pengembangan strategi pasar hingga komersialisasi dengan pelaksana adalah pelaku bisnis/UKM sedangkan Incubator bisnis berperan sebagai pendamping dan fasilitasi mentor. Selama ini proses yang kosong tersebut dilakukan oleh inovator sendiri, padahal fungsi dan peran inovator di dalam manajemen perguruan tinggi adalah melakukan penelitian, pengajaran, dan pengabdian masyarakat.

\section{KESIMPULAN DAN SARAN}

\section{Kesimpulan}

Pemetaan ekosistem inovasi menunjukkan bahwa terdapat 13 aktivitas utama terkait dengan proses inovasi perguruan tinggi. Berdasarkan hasil karakterisasi, aktivitas pembangkitan ide inovasi meliputi pengembangan agenda riset, pengembangan peta jalan penelitian, dan pengembangan rencana induk penelitian. Kegiatan riset berdasarkan fungsinya dibagi menjadi riset dasar, riset terapan dan riset aksi. Berdasarkan asal dananya, riset dibedakan menjadi penelitian hibah dan joint research. Proses komersialisasi diawali dengan inkubasi hingga peluncuran produk. Kinerja inovasi perguruan tinggi ditentukan oleh jumlah publikasi, jumlah start up, jumlah paten dan banyaknya pemasukan melalui lisensi dan penjualan produk atau teknologi.

Tabel 4. Tahapan komersialisasi teknologi perguruan tinggi

\begin{tabular}{|c|c|c|c|c|c|}
\hline & Imagining & Incubating & Demostrating & Promoting & Sustaining \\
\hline $\begin{array}{l}\text { Hasil yang } \\
\text { diharapkan }\end{array}$ & $\begin{array}{l}\text { Ide teknologi } \\
\text { yang } \\
\text { mengarah } \\
\text { pada pasar }\end{array}$ & $\begin{array}{l}\text { Definisi } \\
\text { kelayakan ide } \\
\text { secara teknis, } \\
\text { komersial dan } \\
\text { potensial untuk } \\
\text { perencanaan } \\
\text { selanjutnya }\end{array}$ & $\begin{array}{l}\text { Pasar siap } \\
\text { menerima } \\
\text { produk/ } \\
\text { teknologi } \\
\text { sesuai pasar }\end{array}$ & $\begin{array}{l}\text { Mendapatkan } \\
\text { penerimaan pasar }\end{array}$ & $\begin{array}{l}\text { Memperluas dan } \\
\text { pentebarkan penggunaan } \\
\text { teknologi dan } \\
\text { mempertahankannya } \\
\text { dalam jangka panjang }\end{array}$ \\
\hline \multirow[t]{3}{*}{$\begin{array}{l}\text { Indikator } \\
\text { keberhasilan }\end{array}$} & $\begin{array}{l}\text { Bukti teknis } \\
\text { dari prinsip } \\
\text { teknologi }\end{array}$ & $\begin{array}{l}\text { Siap dari segi } \\
\text { bisnis dan } \\
\text { perencanaan } \\
\text { bisnis }\end{array}$ & $\begin{array}{l}\text { Meluncurkan } \\
\text { produk }\end{array}$ & $\begin{array}{l}\text { Mendapatkan } \\
\text { bagian } \\
\text { keuntungan pasar }\end{array}$ & $\begin{array}{l}\text { Return of investment } \\
\text { yang memadai }\end{array}$ \\
\hline & Paten & $\begin{array}{l}\text { Produk/ } \\
\text { teknologi }\end{array}$ & & & $\begin{array}{l}\text { Infrastruktur memadai } \\
\text { untuk komersialisasi }\end{array}$ \\
\hline & $\begin{array}{l}\text { Visi awal } \\
\text { teknologi }\end{array}$ & Uji pasar & & & \\
\hline
\end{tabular}




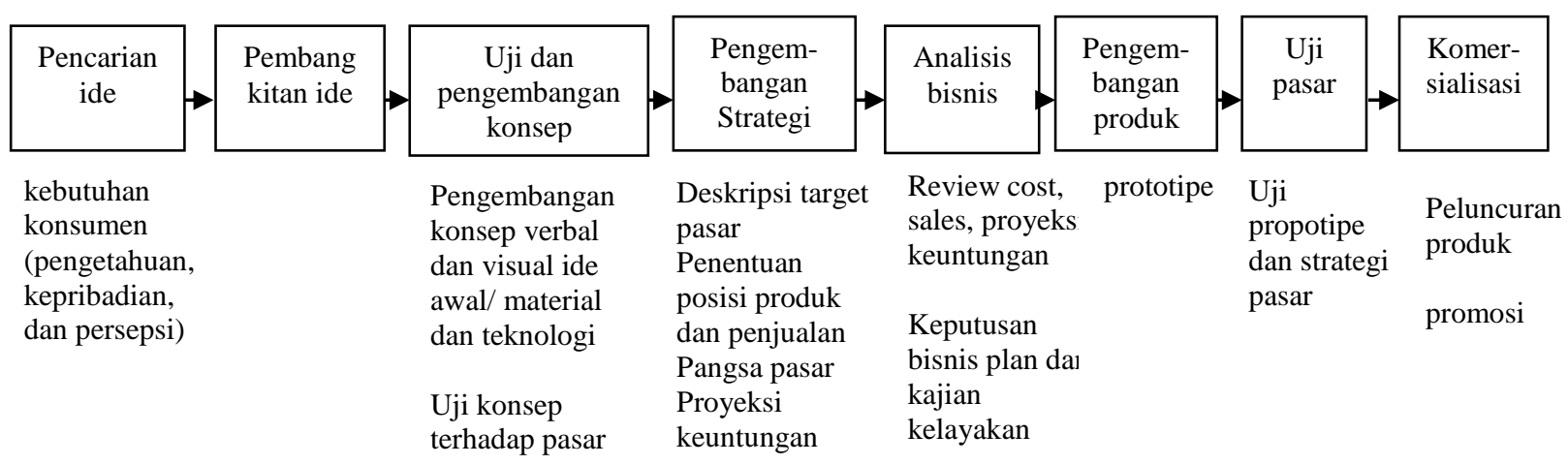

Gambar 11. Tahapan proses komersialisasi (Cooper, 2006; Bhuiyan, 2011; Amue dan Adiele, 2012)

Perguruan tinggi mendukung peningkatan kinerja inovasi mahasiswa melalui pemberian reward kepada mahasiswa melalui kegiatan pekan kreativitas mahasiswa dan kegiatan wirausaha mandiri. Hasil inovasi dari mahasiswa diperoleh sebagian besar melalui kegiatan kreativitas.

Berdasarkan analisis kesamaan peran, terdapat kesamaan peran di dalam manajemen inovasi IPB yaitu pada fasilitasi kerjasama penelitian, peran inkubasi, peran fasilitasi perlindungan hak kekayaan intelektual dan peran diseminasi inovasi dalam bentuk pameran. Berdasarkan analisis kesenjangan, peran proses tahapan komersialisasi seperti uji dan pengembangan konsep, analisis bisnis, pengembangan produk belum dilakukan oleh pemangku kepentingan IPB.

\section{Saran}

Pemetaan ekosistem inovasi menunjukan bahwa masih terdapatnya peran ganda dan tidak adanya peran seperti peran analisis bisnis dan pengembangan produk yang belum difasilitasi didalam manajemen inovasi IPB yang menimbulkan aliran koordinasi masih belum berjalan baik. Penelitian analisis jaringan sosial dapat digunakan untuk menjawab permasalahan aliran koordinasi antar aktor IPB karena analisis jaringan sosial mengukur dan menggambarkan struktur hubungan antar entitas secara lebih detail. Penelitian yang dapat dilakukan peneliti selanjutnya adalah melakukan analisis jaringan sosial untuk memahami jenis hubungan antara pemangku kepentingan (formal dan informal) dan jenis aliran yang terjadi (komunikasi, koordinasi atau pengetahuan). Selain itu, penelitian mengenai pemetaan ekosistem inovasi di lingkungan perguruan tinggi dapat menambahkan peran pendidikan dalam sistem inovasi IPB.

\section{DAFTAR PUSTAKA}

Adner R. 2006. Match your innovation strategy to your innovation ecosystem. Harv Bus Rev. 84 : 98-110.

Ameka I dan Dhewanto W. 2013. Technology push vs. market pull in technology university innovation commercialization case study: ITB. Inf. manag. Bus. Rev.5(7 ) : 337-341.

Amule GJ dan Adiele KC. 2012. New product development and consumer innovative behaviour: an empirical validation study. Eur. Journal Business Social Science. 1(6): 97-109.

Baglieri D, Baldi F, dan Tucci C. 2015. University Technology Transfer Office Bussiness Models : One Size Does Not Fit All. DRUID. Rome (IT): LUISS

Boeddrich HJ. 2004. Ideas in the workplace: a new approach toward organizing the fuzzy front end of the innovation process. Creativity Innov. Manage. 13 (2): 274-285.

Bhuiyan N. 2011. A Framework for Successful New Product Development. Journal Ind. Eng. Management 4(4): 746-770.

Cho YH, Kim JK, dan Kim SH . 1998. Role-based approach to business process simulation modeling and analysis. Computers Ind. Engng. 35(2) : 343 - 346.

Cooper RG. 2006. Formula for success in new product development. Market Manage Mag. (Maret-April) : P 18-24.

Engler J dan Kuslak A. 2011. Modelling an Innovation Ecosystem with Adaptive Agent. International Journal Innovation. Science.3(2): 55-67.

Eisenhardt KM dan Graebner ME. 2007. Theory building from case : opportunity and challange. Acad. Management Journal 50 : 25-32.

Guerrero M dan Urbano D. 2012. The Development of an entrepreneurial university. Journal Technology Transf. 37(1) : 43-74.

[IPB] Institut Pertanian Bogor. 2012. Rencana Induk Penelitian 2012-2025. Bogor (ID) : IPB.

2013. Naskah Akademik Sistem Inovasi Institut Pertanian Bogor. Bogor (ID) : IPB.

Jiao H, Alon I, dan Cui Y. 2011. Environmental dynamism, Innovation and dynamic capabilities: the case of China. Journal Enterp. Community. 5 (2): 131-144. 
Nachira F, Dini P, dan Nicolai A. 2007. A Network of Digital business ecosystem for Europe: Roots, Processes, and Perspectives. Dalam Nachira F, Dini P, Nicolai A, Le Louarn M, Leon RL (Ed). Digital business ecosystems. European Commission: Luxembourg. 1-20

[OECD] The Organisation for Economic Cooperation and Development. 1981. The Measurement of Scientific and Technical Activities. Frascati Manual. Paris (FR): OECD.

.2015. Concepts and definitions for identifying R\&D. Frascati Manual. Paris (FR): OECD.

Ortega LM dan Bagnato VS. 2015. The practice od innovation at brazilian public universiy : the case of the University of Sao Paulo. Brazil Journal Science Technolology. 2(6): $1-15$.

Okpara FO. 2007. The value of creativity and innovation in entrepreneurship. Journal Asia Entrep Sustain.3(2) : 81-93.

Palys T. 2008. Basic Research. Di dalam Given LM (Ed.) The Sage Encyclopedia of Qualitative Research Methods. Thousand Oaks: P57-59.

Partner H dan Carisgold. 2002. Best Practice Processes for University Research Commercialisation Final Report. Canberra (AUS): Commonwealth Departemen of Education, Science and Training.
Takata M. 2011. Study of the process of university technology commercialization: the roles and effects of educational courses. Intenational Journal Eng. Innov. Manage. 1 : 15-28.

Tohidi H dan Jabbari MM. 2012. Presenting new product in the process innovation. Soc Behav Sci. 31 : $891-893$.

Regele MD dan Neck MH. 2012. The entreprenurship education sub-ecosystemin the united states : opportunities to increase entrepreneurial activity. Journal Bus Entrep 23(2): 25-47.

Rohrbeck R, Holzle K, dan Gemiiden HG. 2009. How Deutsche Telekom Create an Open Innovation Ecosystem. $R \& D$ Manage. 39(4): 420-430.

Voight KI dan Brem A. 2009. Integration of market pull and technology push in the corporate front end and innovation managementinsight from the German Software Industry. Technovation. 29 : 351-367.

Yin RK. 2003. Case Study Reseach Design and Methode. 3rd Eds. London: Sage Publication. 